\title{
Study on forest tenure in Vietnam in terms of justice, dispute resolution, gender, pro-poor and inclusiveness
}

\author{
Hương dụng rùng ở Việt Nam về các khía cạnh công bằng, giải quyết tranh \\ chấp, giới, vì người nghèo và sụ bao trùm \\ Research article
}

Thi Tuyet Anh Le ${ }^{1 *}$, Lien Son Hoang ${ }^{2}$

${ }^{I}$ Department of Environmental Science, Memorial University of Newfoundland, NL, Canada; ${ }^{2}$ Forestry Economics Research Centre, Vietnamese Academy of Forest Sciences, Vietnam

\begin{abstract}
This article is an important content of the research on "Assessment of Forest Tenure Policies and Regulation in Vietnam ". This assessment reviewed 79 legal documents related to forest land tenure that includes: 1 Constitution; 8 Laws; 1 Resolution; 20 Decrees; 30 Circulars, 18 Decisions and 1 Directive. The objective of this paper was to assess some facets of Justice, Dispute Resolution, Gender, Pro-poor and Inclusiveness in the system of Vietnam forest tenure policies. The main research method was based on the assessment framework Voluntary Guidelines on the Responsible Governance of Tenure of Land, Forests and Fisheries. The results of 2 theme groups (a-Access to justice and resolution of tenure rights; and b-Gender equity and pro-poor and inclusiveness), corresponding to the seven sub-themes/criteria showed that its marks were at from 1 to 2 (the system of forest tenure policies in Vietnam has attained "slightly addressed" to "moderately addressed" for the facets of forest tenure rights), has not gained the levels of "mostly addressed" (mark 3) or "fully addressed" (mark 4).
\end{abstract}

Bài báo này là một phần nội dung quan trong của nghiên cứu "Đánh giá các Chính sách và Quy định hưởng dụng rùng ở Việt Nam". Công trình nghiên cứu đã rà soát phần lớn các chính sách hiện hành quan trọng của huởng dụng rừng với tổng số 79 văn bản, gồm: 1 Hiến pháp; 8 Luật; 1 Nghị quyết; 20 Nghị định; 30 Thông tu; 18 Quyết định và 1 Chỉ thị. Mục tiêu của bài viết này là đánh giá các mặt công bằng, giải quyết tranh chấp, giới, vì người nghèo và sư toàn diện trong hệ thống các chính sách huơong dưng rừng ở Việt Nam. Phuơng pháp nghiên cứu chính được dưa trên khung đánh giá của Huớng dẫn tư nguyện về Quản trị chịu trách nhiệm của huởng dụng đất, lâm nghiệp và thủy sản. Kết quả nghiên cứu 2 nhóm chủ đề (a-Tiếp cận đển sư công bằng và giải pháp giải quyết tranh chấp hưởng dưng; b-Giới và công bằng, vì nguời nghèo và sư toàn diện), tuoơng ưng với 7 chủ đề phu/tiêu chi đều cho thấy mói đạt mức điểm tù̀ 1 - 2 (tức là hệ thống chính sách huơơng dụng rùng hiện hành ở Việt Nam mói "giải quyết một phần" đến "giải quyết trung bình" các khía canh về quyền huoơng dụng rùng), chứ chura "giải quyết phần lớn" (điểm 3) hoặc "giải quyết đầy đư” (điểm 4).

Keywords: assessment of forest tenure rights; forest tenure policies; justice, dispute resolution, gender, pro-poor and inclusiveness

\section{Introduction}

Forest tenure (FT) is a broad concept that shapes the relationship between people with respect of forests by defining who can use what resources, for how long, and under what conditions. It is a bundle of rights which encompasses rights to manage, use, exclude, access and alienate.
However, tenure and ownership are not the same although most of people frequently use these terms interchangeably. Ownership refers to a particular type of tenure in which a more complete bundle of rights is allocated to the rights holders. It provides right to sale or alienates the resources. Ownership of forest and forestland is broadly divided into two categories: public and private [5]. 
In Vietnam, there is 33.12 million hectare (Mha) of the total national inland territory, of which forest covers 13.79 Mha, representing approximately $40 \%$ of the total area of Vietnam (VNFOREST, 2015). Before "Doi Moi" policy (economic reform) initiated in 1986, most forests were under government management and administration. In 1990s, legal framework related to forest tenure (FT) changed toward inclusion of multi-stakeholders in the management of forests, such as private sector, communities, and individual households [8].

According to Law on Forest Protection and Development 2004 (LFPD, 2004) and the Decision No.3135/QD-BNNTCLN dated $06^{\text {th }}$ August 2015, there are 8 stakeholders actively engaged in managing forestland and forest areas in Vietnam: State organizations (Forest Management Board for special use forest and protection forests; State Forest Company, army and mass organizations); private sector (other economic organizations, individuals and households); village community; and Commune People's Committee (CPC) [12]. In the last 20 years, Vietnam has adopted the process of change in forest policies and institutions by reforming FT. As a result, forest areas have been increasingly allocated to private sectors such as individuals and households.

One of the most important contents of FT policy system is for all walks of life in the local communities to gain the justice, pro-poor and inclusiveness that have the dispute resolution reasonably and gender issue integrated. Against this backdrop, this article focuses on review of current FT policies to find out the qualitative evidences, policy gaps and suggests practical recommendations to address policy gaps for those in terms of Justice, Dispute Resolution, Gender, Pro-poor and Inclusiveness.

\section{Materials and methods}

This article focused on 2 key laws in Vietnam, Land Law 2013 (LL, 2013) and LFPD, 2004 and nearly 77 bylaws concerned. The assessment framework of this article covered 2 thematic areas related to Justice, Dispute Resolution, Gender, Pro-poor and Inclusiveness in FT rights to review against the qualitative indicators/benchmarks developed for each theme as per guiding and implementation principles of the Voluntary Guidelines on the Responsible Governance of Tenure of Land, Forests and Fisheries (VGGT). These themes were analyzed with the help of diagnostics questions as sub themes (criteria) to summarize the qualitative assessment with the use of Likert scaling from 0 to 4 ( 0 for not addressed at all, 1 for partially addressed, 2 for moderately addressed, 3 for mostly addressed, and 4 for fully addressed) and find out the missing elements in the current FT policies. The ranking will be substantiated by the concrete evidences as provisioned under the existing regulatory framework such as: policies, laws, rules, regulation, and guidelines etc.

The project researched 8 themes, including:

(i) Legal recognition and respect of rights;

(ii) Legal allocation and transfer of tenure rights;

(iii) Access to justice and resolution of tenure rights; (iv) Gender equity and pro-poor and inclusiveness;

(v) Role and responsibility of state and non-state actors;

(vi) Responses to climate change and emergencies

(vii) Sustainable forest management and administration of tenure;

(viii) Responses to livelihoods of forest dependents.

Topics (iii) and (iv) and their sub-themes have been chosen for this paper, following:

(iii) Access to justice and resolution of tenure disputes

- Measures and mechanisms are in place for the resolution of tenure disputes;

- Effective and accessible means and provision to access judicial authorities or other approaches to resolve disputes over tenure rights;

- Strategies to prevent tenure disputes from arising and escalating to violent conflict.

\section{(iv) Gender and equity, pro-poor and inclusiveness}

- Gender sensitiveness that ensures equal tenure rights for male and female, indigenous and other marginalized groups over access and use of forestland and resources;

- Special mechanism that supports and encourages the role of poor and marginalized;

- Provision that ensures inclusiveness and participation of all stakeholders in forestry;

- Legitimate tenure holders receive equitable benefits from forests and forestland.

\section{Results and discussion}

\subsection{Access to justice and resolution of tenure disputes}

\subsubsection{Measures and mechanisms are in place for the resolution of tenure disputes}

According to Clause 1 of Article 202 of Land Law 2013 (C1 A202 LL, 2013), the State encourages the conflicting parties to reconcile and resolve their problem locally. If the self-reconciliation fails, the parties may send a petition to Commune People's Committee (CPC) as provisioned under C2, C3 A202 LL, 2013; and Division of Natural Resources and Environment, Department of Natural Resources and Environment for settlement (C5 A202 LL, 2013). If the reconciliation at a CPC level fails, a land dispute shall be settled at the People's Court or at competent People's Committee (C1, C2 A203 LL, 2013). For forest land, the C1 A84 LFPD, 2004 stated: "Disputes over the rights to use forests of all kinds and/or the ownership rights over planted production forests shall be settled by the People's Courts. Disputes over forested land and/or afforestation land shall be settled according to the existing LL". Any cases of violation of Forest Laws shall be dealt in accordance with the provisions stipulated in A85, A86 LFPD, 2004. 


\section{Policy gaps and recommendations}

The existing provisions related to the settlement of land disputes or complaints are not clear and convincing as the regulated settlement steps $(\mathrm{C} 2, \mathrm{C} 3, \mathrm{C} 4$ and C5 A202, C2, C3, C4 A203 LL, 2013) do not refer to the role of lawyers and legal bodies. Instead, the handling of tenure disputes by chairperson of People's Committee. It also fails to mention the role of relevant advisory and consultancy bodies in disputes settlement. In addition, other factors such as customs, traditional ethic, convention, customary laws, and cultural village based regulations have not yet been taken into account in the process of disputes resolution.

Therefore, there is a need to clarify the provisions on dispute resolution and complaints related to land as well as the measures and resolution mechanisms of land tenure right disputes.

3.1.2. Effective and accessible means and provision to access judicial authorities or other approaches to resolve disputes over tenure rights

Regarding complaints, denunciations and feedback mechanisms, land users are entitled to claim complaint or file lawsuits on land on the basis of A204, A205 LL, 2013; and the A19 of Decree (De) No. 45/2014/ND-CP stipulating the collection of land use levies. Land users are entitled to carry out scientific research on issues related to FT rights (C5 A59 LFPD, 2004) to take proper complaints, grievances and submission to the competent authorities and agencies for settlement.

\section{Policy gaps and recommendations}

The existing complains mechanisms have revealed a number of shortcomings as there are unequal access to government agencies. In addition, the process of handling tenure disputes does not explicitly reflect the basis of commitment and dialogue among relevant parties. The process is too complex and cumbersome, as a result, it is too difficult to follow the application process or some time fails to make use of existing facilities such as: information and communication system, particularly by the rural communities. Furthermore, the FT dispute handling mechanism is too generic (C2 A85 LFPD, 2004) and the role of counseling agencies or forest scientific bodies are not mentioned explicitly in the process of handling disputes related to FT.

It is recommended to simplify the judicial process so that every individual can access and enjoy the services.

\subsubsection{Strategies to prevent tenure disputes from aris- ing and escalating to violent conflict}

People-based strategy is considered as viable option to prevent tenure disputes and any violent conflicts. Communal authority is the main body to settle tenure disputes. It is initially encouraged to follow a self-reconciliation mechanism. In case it fails then communal authority should play a role to settle tenure disputes (A202 LL, 2013).

\section{Policy gaps and recommendations}

The institutionalized provisions about prevention of tenure disputes are rather vague and complicated, therefore there is a need to simplify it and ensure effectiveness. In addition, there are certain shortcomings such as unclear methods/forms of reconciliation. So far, the legal value of the reconciliation results has not yet been realized. CPC does not have enough capacity to deal with sanctions against the parties that do not follow the reconciliation results. Likewise, current provisions ignore the role of indigenous people, lawyers, and legal bodies in the process.

Thus, the strategies should be developed in a clear, reasonable, fair way and integrated in the relevant bylaws to prevent land tenure disputes

\subsection{Gender and equity, pro poor and inclu- siveness}

3.2.1. Gender sensitiveness that ensures equal tenure rights for male and female, indigenous and other marginalized groups over access and use of forestland and resources

There are laws to ensure equal rights of both male and female over the property in a family as stipulated in the A219 of the Law on Population, and C2 A18 of the Law on Gender Equity, 2007. Gender sensitivity is maintained in land tenure as Land Use Right Certificate (LURC) includes names of both men and women. Such provision is included in the C2, C4 A98 LL, 2013 and Point c, d C1 A5 of Circular (Ci) No. 23/2014-TT -BTNMT. Due attention has been placed by A27 LL, 2013 on land use rights for vulnerable groups such as women, the poor, ethnic minorities. Furthermore, those groups are entitled to get priority on land allocation, exemption and reduction of land use/lease (A54; A110 LL, 2013; from A10 to A12 De No. 45/2014/ND-CP).

\section{Policy gaps and recommendations}

The gender issues have not indicated clearly in most of FT processes. There are need additional provisions on gender sensitiveness in LFPD and relevant bylaws.

\subsubsection{Special mechanism that supports and encour- ages the role of poor and marginalized people}

There are a number of policies and regulation those support and encourage poor and vulnerable/disadvantaged groups by enhancing their role in FT and providing special priorities. Some of them are focused below:

- Policy on exemption, reduction of land use/leases levies applicable to the poor and other disadvantaged groups (A54; A110 LL, 2013; from A10 to A12 De No. 45/2014/ND-CP);

- Policy supporting social housing for disadvantaged groups (A11 De No. 45/2014/ND-CP; Decision (Dn) No. 167/2008/QD-TTg); 
- Policy on poverty reduction for people living in and around forest area, especially disadvantaged groups (Resolution (Re) No.30a/2008/NQ-CP; Circular (Ci) No.08/2009/TT-BNN; Inter-ministerial Ci No. 52/2008/TTLT BNN-BTC; De No. 80/2011/NQ-CP; Dn No. 11/2011/QD-TTg; Ci No. 58/2009/TT-BNN, etc.); and

- Policy for people living in resettlement areas (Dn 64/2014/QD-TTg; Dn No. 459/QD-TTg, Dn No.138/2000/QD-TTg, Dn No. 1489/2012/QD TTg).

\section{Policy gaps and recommendations}

There is no FT policies for each vulnerable group such as women (poor, ethnic minorities, disable people, people with HIV/AIDS or other chronic diseases. Therefore, it should be specified the mechanisms to support for the poor and other disadvantaged people in forest areas.

\subsubsection{Provision that ensures inclusiveness and partici- pation of all stakeholders in forestry}

Provisions on inclusiveness and participation of all stakeholders in forestry are mentioned in the following policy documents:

- Identify the stakeholders in the forestry sector (A5, A8 LFPD, 2004);

- There exist mechanisms and policies to mobilize the participation of social resources (from A22 to A25 and A 27, A28 LFPD, 2004; De No. 106/2004/NĐ-CP; Dn No. 67/1999/TTg; Dn No 178/2001/QĐ-TTg; De No. 48/2007/NĐ-CP; De No. 99/2010/NĐ-CP).

\section{Policy gaps and recommendations}

There are some missing elements:

- Forest owners being village communities have not been included in A5 LFPD, 2004;

- Absence of separate policies, legal documents regulating the roles of Non-Government Organisations (NGOs) or Civil Society Organizations (CSOs) in forestry sector development;

- Dn No.178 reveals certain constraints (especially benefit sharing mechanism between the State and households on timber);

- - Low revenue from Paying for Environmental Services (PES).

It is recommended to revise, supplement, and finalize policies targeting village communities in the forestry sector. It is also suggested revising and supplementing some articles of De No. 48; De No. 99 and the entire Dn No.178.

\subsubsection{Legitimate tenure holders receive equitable ben-} efits from forests and forestland

The legitimate forest and forest land users are entitled for the 8 common rights (A59 LFPD, 2004) and the 6 common obligations (A60 LFPD, 2004). Each type of forest owner has its own regulations on benefits (from A61 to A78 LFPD, 2004). The existing forest policies and mech- anisms have gradually created a legal framework to enable the legitimate forest users to get direct and indirect benefits from the forest management (Dn No.178/2001/QD-TTg, Dn No.147/QD-TTg, Dn No. 380/2008/CP; Re No. 99/2010/ND-CP; Ci No. 80/2011/TT-BNN; Dn No.799/QD-TTg).

\section{Policy gaps and recommendations}

There are some main shortcomings:

- Unequal benefit sharing amongst forest users/owners:

+ It's irrational for the Government to allocate production forest (poor and average natural forests) but collect forest use fee from economic organizations (Point b C3 A24 LFPD, 2004).

+ Not fair in ways of fee collection of different forest owners (A25 LFPD, 2004).

- Some shortcomings in collection of forest use fee:

+ Decision 178: Most of households participating in land and forest allocation are poor to invest. It's hard to effectively protect allocated poor forest and it takes time to get benefits from wood exploitation.

+ PES policies: Low PES revenue, late payment which have not fully reflected the principle of results based payment.

Therefore, it is recommended to revise and supplement Point b C3 A24 and A25 LFPD, 2004; shortcomings in Decision No. 178 and PES policies in a timely, complete and easy way.

\subsection{The consolidated results and discussion}

The assessment results based on the Likert scale ranked were drawn with specific score for each sub theme and aggregated value of each criterion was divided by the number of sub themes to calculate the score for each theme. Each sub-theme is expected to the highest score at the point of 4 in the VGGT's rank. These information was summarised in the table 1.

\begin{tabular}{|c|c|c|c|}
\hline No & Themes/Criteria & $\begin{array}{l}\text { Current } \\
\text { marked } \\
0-4^{*}\end{array}$ & $\begin{array}{l}\text { Score } \\
\text { expected }\end{array}$ \\
\hline $\mathbf{a}$ & $\begin{array}{l}\text { Access to justice and resolu- } \\
\text { tion of tenure disputes }\end{array}$ & 1.67 & 4 \\
\hline $\mathrm{i}$ & $\begin{array}{l}\text { Measures and mechanisms are } \\
\text { in place for the resolution of } \\
\text { tenure disputes }\end{array}$ & 2 & 4 \\
\hline ii & $\begin{array}{l}\text { Effective and accessible means } \\
\text { and provision to access judicial } \\
\text { authorities or other approaches } \\
\text { to resolve disputes over tenure }\end{array}$ & 1 & 4 \\
\hline iii & $\begin{array}{l}\text { Strategies to prevent tenure } \\
\text { disputes from arising and } \\
\text { escalating to violent conflict }\end{array}$ & 2 & 4 \\
\hline $\boldsymbol{b}$ & $\begin{array}{l}\text { Gender and equity, pro poor } \\
\text { and inclusiveness }\end{array}$ & 1.88 & 4 \\
\hline $\mathrm{i}$ & Gender sensitiveness that & 2 & 4 \\
\hline
\end{tabular}

* Extent of addressing principles of VGGT: 0 - not addressed at all;1- slightly addressed, 2-moderately addressed, 3- mostly addressed, 4-fully addressed 


\begin{tabular}{lll} 
No Themes/Criteria & $\begin{array}{c}\text { Current } \\
\text { marked } \\
0-4^{*}\end{array}$ & $\begin{array}{l}\text { Score } \\
\text { expected }\end{array}$ \\
\hline
\end{tabular}

ensures equal tenure rights for male and female, indigenous and other marginalized groups over access and use of forestland and resources.

Special mechanism that sup-

ii ports and encourages the role of poor and marginalized.

Provision that ensures inclu-

iii siveness and participation of all stakeholders in forestry

Legitimate tenure holders

iv receive equitable benefits from forests and forestland

Table above shows that none of the sub-themes is fully addressed by the current regulatory framework on forestland tenure in Vietnam. Most criteria rated the marks at point of $2 / 4$ that their current marks were a half of level expected, indicate that current regulatory framework moderately addressed those issues. The sub-themes of "effective and accessible means and provision to access judicial authorities or other approaches to resolve disputes over tenure" and "legitimate tenure holders receive equitable benefits from forests and forestland" were the lowest at 1 and 1.5/4 respectively which mean there is an urgent need to revise or promulgate new policies and laws in favor of theme to gain the effective and accessible means and provision to access the authorities as well as to resolve the disputes in FT, besides the legitimate stakeholders also need the clear mechanisms or policies for them to receive the equitable benefits from $\mathrm{FT}$.

The current score obtained by each theme is summarised in the column 2 and 3 of table 2. However, the expected improvement under each theme is 4 (the highest score) within the Likert scale. The figure 1 below describes the current and expected score in future under each subtheme. The highest score would be possible to achieve only through strong political will, institutional capacity and enabling policy environment to strengthen forest land tenure and improve the livelihoods of forest dependent communities.

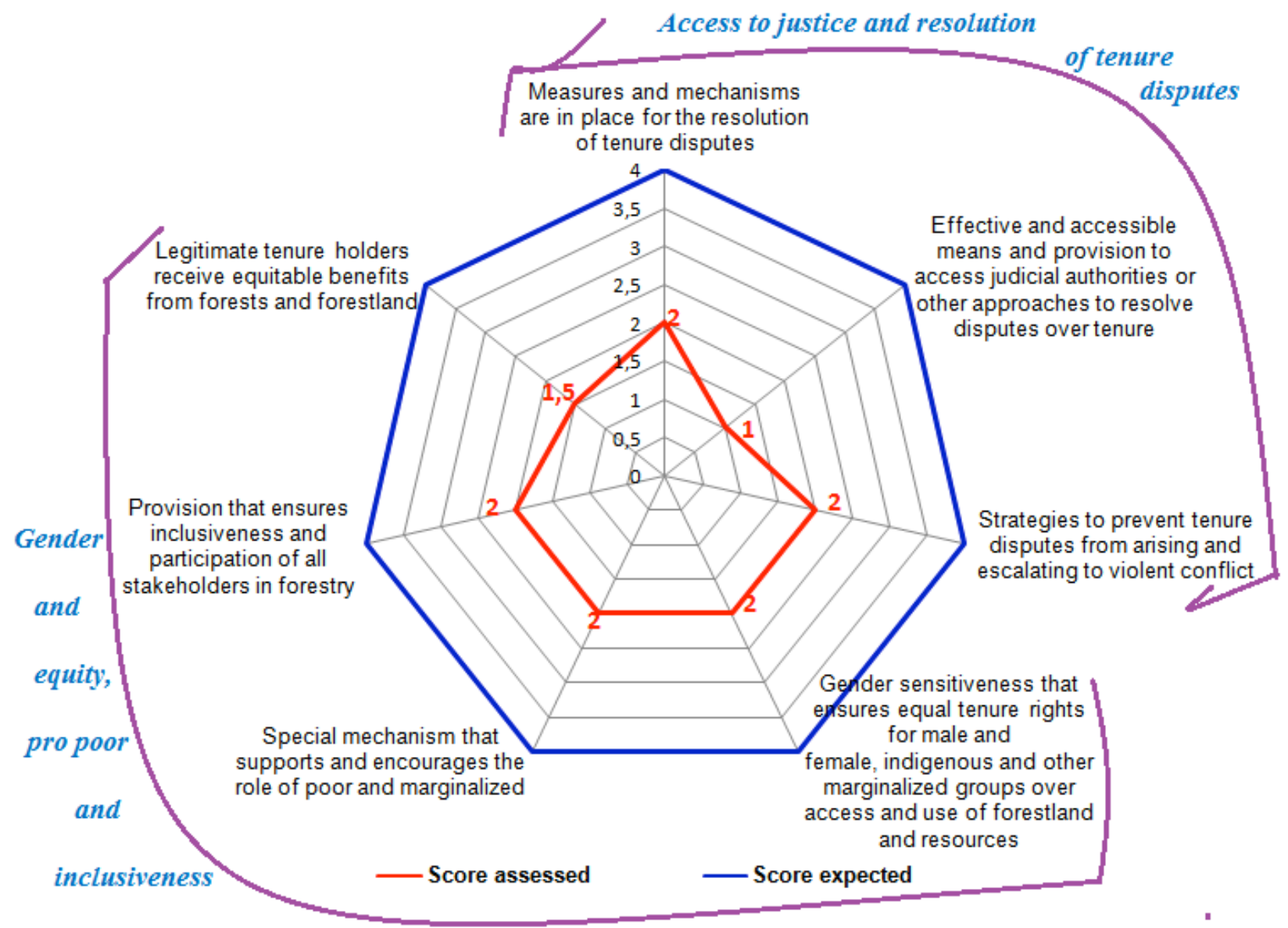

Figure 1. Current and expected score under each theme

Policy assessment further emphasized the need of clear mechanism for compensation in case government wants to take over any forests or forestland from individual households to local communities, especially the vulnerable people for them to attain the justice, pro-poor and inclusiveness.

\section{Conclusion}

This assessment reviews 2 key laws (LL, 2013 and LFPD, 2004) and the bylaws related to FT rights of these laws. Most of the bylaws were promulgated to create a complete legal framework. The LFPD, 2004 has created a quite comprehensive legal basis for forestry activities 
although its title only refers to forest protection and development. Most of the elements of bundle of rights such as: access, use, management, exclusion, and alienation are recognized by the current regulatory framework; clear and explicit mechanism devised to allocate and transfer FT rights and duties from the state to legitimate forest owners and have 8 rights secured with 6 common obligations [12].

Despite having certain strengths of existing regulatory framework in Vietnam there exists a number of shortcomings and limitation which inhibit the process of access to justice, dispute resolution, pro-poor and inclusiveness that issue of gender integrated.

The outcomes of assessment on forest tenure policies and institutional capacity have clearly informed a set of policy and capacity gaps. These gaps should be addressed immediately so that the policy objectives could be achieved more efficient and effective way. The unfolding policy reform process in Vietnam should consider the assessment result as a basis to modify existing policies and regulation or formulate new so that the management of forest land could contribute in reducing poverty and improving livelihoods of millions of forest dependent communities in Vietnam. The most important strategy to implement agreed action plans is to establish a strong collaboration and cooperation amongst stakeholders to ensure collective implementation of these action plans. Sharing resources and complementing each other should be the approach to make sure that the proposed action plans are implemented effectively on the ground. In addition, there should be a strong commitment from the key actors who are directly involved in strengthening forest land tenure in Vietnam. Amending existing policies or formulation of new policies is time taking process and requires support from multiple agencies therefore synergy among key actors will be instrumental.

This is a desk-study policies' review, meanwhile the system of FT policies in reality is very different, even many actions concerned run in an opposing manner in comparison with the current policies issued. Thus, there is essential and urgent to have more researches to deepen the FT policies in various areas in Vietnam to reach the bright and detail results. This is the most effective solution to find, build and complete any policy in general and FT policies in particular.

\section{References}

[1] Bebbington, Anthony (1999):“Capitals and capabilities: A framework for analyzing peasant viability, rural livelihoods, and poverty". World Development, 27(12), 2012-2044.

[2] Bradstock, Alanstair (2005): "Changing livelihoods and land reform: Evidence from the Northern Cape Province of South Africa". World Development, 33(11), 1979-1992.

[3] Cahn, Miranda (2002): "Sustainable livelihoods approach: Concept and practice". Paper presented to Dev Net 2002 Conference on Contesting Development: Pathways to Better Practice, The Institute of Development Studies at Massey University, 5-7 December, New Zealand.

[4] Dahal GR (2015): "Forest land tenure policy and legal assessment - Vietnam", A presentation at the first national policy dialogue on Strengthening Forest Tenure for Sustaining Livelihood and Generating Income.

[5] FAO (2015): “A Framework for Forest Tenure Policy Assessment in the context of Strengthening Forest Tenure for Sustaining Livelihood and Generating Income". FAO, 2015.

[6] Nguyen Ba Ngai et all (2009)- "Forestry and Poverty Data in Vietnam: Status, Gaps, and Potential Uses". A reference book.

[7] MARD (2013): "The assessment of 10 years of implementation of Law on Forest Protection and Development 2004”. MARD Publications, Hanoi.

[8] MARD (2005): "Some issues of community forest, conservation and development of forests in Vietnam". Thematic Information, Vol. 3-2005.

[9] Hoang Lien Son, Le Thi Tuyet Anh (2016): "Forest Tenure Policy Assessment in Vietnam". The last research report of the project "Strengthening Forest Tenure for Sustaining Livelihood and Generating Income". Hanoi, July 2016.

[10] Nguyen Quang Tuyen et al (2013): "Mediation in Vietnam land disputes - Analysis of current laws, practices and recommendations for reform"-Full report.

[11] Law on Land. Law No. 45/2013/QH13 of the National Assembly.

[12] Law on Forest Protection and Development. Law No. 29/2004/QH11 of the National Assembly. 